\title{
叶附生苔植物物种多样性分布格局及生态成因
}

\author{
姜炎涁 ${ }^{1}$ 邵小明 ${ }^{2 *}$
}

1华中农业大学资源与环境学院, 武汉 $430070{ }^{2}$ 中国农业大学资源与环境学院, 生物多样性与有机农业北京市重点实验室, 北京 100193

摘 要 叶附生苔植物(以下简称叶附生苔)是一类附生在维管植物叶片表面的、一般只出现在热带雨林和常绿阔叶林中的苔 类植物。它们具有重要的生态功能, 如影响碳、氮、水循环, 对气候变化和森林破碎化反应敏感, 可用作环境变化的指示植 物。该文对叶附生苔的形态特性、物种多样性的研究历史和进展、地理分布格局, 以及对环境的要求(附主和生境的特性)等 进行了综述, 探讨了叶附生苔多样性分布格局形成的可能原因, 即环境(空气湿度高、林冠层发育好、干扰少)和适应特征(无 性繁殖、形体微小)的选择。根据全球叶附生苔研究进展状况及所存在的问题提出未来可开展的研究方向, 如叶附生苔的形 成原因、与附主间的物质交换和能量流动机制、在森林生态系统中的生态功能、气候变化指示作用研究等, 大尺度上的研究 也值得关注。

关键词 苔藓植物; 物种多样性; 地理分布; 环境

引用格式: 姜炎涁, 邵小明 (2016). 叶附生苔植物物种多样性分布格局及生态成因. 植物生态学报, 40, 523-532. doi: 10.17521/cjpe.2015.0359

\section{Diversity and distribution pattern of epiphyllous liverworts and its ecological determinants}

JIANG Yan-Bin ${ }^{1}$ and SHAO Xiao-Ming ${ }^{2 *}$

${ }^{1}$ College of Resources and Environments, Huazhong Agricultural University, Wuhan 430070, China; and ${ }^{2}$ Beijing Key Laboratory of Biodiversity and Organic Farming, College of Resources and Environmental Sciences, China Agricultural University, Beijing 100193, China

\begin{abstract}
Epiphyllous liverworts form a special group of bryophytes that primarily grow on leaves of understory vascular plants, occurring in constantly moist and warm evergreen forest in tropical and subtropical regions. Epiphyllous liverworts may influence ecosystem processes including carbon, nitrogen and water cycles. Furthermore, they are very sensitive to climate change and forest fragmentation, and can be used as bioindicators for changes in ecological conditions and escalating loss of biodiversity. In this paper, we reviewed studies on morphological traits, species diversity, geographical distribution and environmental conditions (including characteristics of hosts and habitats) of epiphyllous liverworts, discussed the possible reasons for the mechanisms underlying the diversity pattern of epiphyllous liverworts. According to these studies, we proposed that further ecological studies on epiphyllous liverworts should be more focused on their formation, mechanisms of matter exchange and energy flux, ecological functions in forest ecosystem, the response to climate changes and their broader-scale ecology.
\end{abstract}

Key words bryophytes; species diversity; geographical distribution; environment

Citation: Jiang YB, Shao XM (2016). Diversity and distribution pattern of epiphyllous liverworts and its ecological determinants. Chinese Journal of Plant Ecology, 40, 523-532. doi: 10.17521/cjpe.2015.0359

叶附生苔植物(epiphyllous liverworts) (以下简 称叶附生苔)是一类附生在维管植物叶片表面的苔 类植物, 是苔藓植物中最为复杂的一个分类群 (Benavides \& Sastre-De Jesús, 2011)。它们普遍存在 于热带雨林, 在常绿阔叶林中也有分布(陈邦杰和 吴鹏程, 1964)。叶附生苔对于森林生物多样性的形 成和维持、生态系统的物质和能量循环, 以及指示
气候变化、森林完整性等均具有重要意义。

对叶附生苔的初步研究可追溯到19世纪末 (Massart, 1898)。之后, 世界各地越来越多的苔藓学 家和生态学家对叶附生苔开展了相关研究, 内容涉 及分类、生理、分子、生态等方面。对叶附生苔的 物种多样性及生态学方面的研究是长期以来一直在 进行的工作，除了大量的地区性报道和新种或新记

收稿日期Received: 2015-10-11 接受日期Accepted: 2016-02-19

* 通信作者Author for correspondence (E-mail: shaoxm@cau.edu.cn) 
录的报道外, 还有一些系统性的研究, 如: 陈邦杰 和吴鹏程(1964)发表的有关中国叶附生苔的研究 《中国叶附生苔类植物的研究(一)》, 包括了研究 历史、生态与形态特性、地理分布及与邻近地区的 关系以及系统分类等; 匈牙利苔蘚学家Pócs (1996) 发表的关于全球叶附生苔的物种多样性的综述

《Epiphyllous liverworts diversity at worldwide level and its threat and conservation》, 分析了叶附生苔的 区系及地理分布; Zhu和So (2001)的《Epiphyllous Liverworts of China》详细地描述了168种叶附生苔 的特征, 并简要分析了叶附生苔的类型、多样性、 与附主的关系以及分布等特征。近些年来, 应用同 位素示踪技术分析叶附生苔与附主间的生态过程 (Wanek \& Pörtl, 2005), 以及应用分子生物学技术探 讨叶附生苔对特殊生境的适应性(Kraichak, 2012; Yu et al., 2013)等推动了微尺度上叶附生苔的生态 学研究。

总之, 叶附生苔在近几十年受到了较多关注, 尤以其新物种的发现、特征特性以及生态适应性为 研究重点。本文将以叶附生苔为研究对象, 结合其 生境的特性, 着重从其物种多样性和生态分布等方 面展开探讨, 综述全球叶附生苔物种多样性分布格 局和生态成因方面的研究进展, 为进一步开展叶附 生苔的研究提供参考和建议。

\section{1 叶附生苔的物种多样性}

\section{1 叶附生苔的形态特性}

叶附生苔是苔类植物中的一个特殊类型, 生长 于湿润环境中, 兼有气生(生于叶表)及适度耐旱(长 期无雨, 叶表偏干)等特性, 在形态结构上有以下特 征: (1)植物体弱小、扁平且左右对称, 有明显的背、 腹面之分; (2)茎腹面通常生长有束状的假根, 使之 适应于附生生活; (3)叶片呈覆瓦状排列, 以利于叶 片在空气湿度或者光照变化时进行相应的活动, 充 分吸收水分或者防止水分的散失; (4)多数有腹叶, 或者侧叶有内卷的腹瓣, 可强烈卷起形成空腔, 用 于蓄水以保持湿润; (5)生殖方式以无性繁殖为主, 叶片腹面、叶尖或叶片后缘常产生芽胞, 可借助于 水雾直接散布, 萌发形成植株; (6)少数叶附生苔种 类利用细胞壁加厚形成疮等结构产生防旱特性, 在 空气蒸发量大、湿度低、叶细胞收缩时, 疮与病之 间的距离缩小, 以反射阳光、减少水分蒸发, 而当空
气湿度升高时, 疮间空隙可起毛细管作用, 迅速吸 收空气中水分, 使植物恢复正常生活状态; (7)蒴苍 扁平(陈邦杰和吴鹏程, 1964; Zhu \& So, 2001; Kraichak et al., 2012; Yu et al., 2013)。

\section{2 叶附生苔的物种多样性}

1898年法国学者Massart发表了第一篇有关叶 附生苔的研究。1900-1924年, 德国苔类植物学家 Stephani在《Species Hepaticarum》上报道了叶附生 苔 (Stephani，1900，1906，1906-1909，1909-1912, 1912-1917, 1924)。此后, 叶附生苔开始引起世界不 同地区许多苔藓植物学家和生态学家的关注。

亚洲地区对叶附生苔的报道稍晚, 但一直延续 至今。Schiffner (1929) 报道了日本的叶附生苔; Kamimura (1939)描述了日本四国岛(Sikoku)的附生 在86种附主上的46种叶附生苔。Mizutani (1966)报 道了马来西亚沙巴州的2科17属79种叶附生苔, 以 及菲律宾的44种叶附生苔。印度叶附生苔的研究也 有多次报道(Pande \& Misra, 1943; Dey et al., 2008; Asthana \& Shukla, 2009, 2010; Dey \& Singh, 2010)。 斯里兰卡(Eggers \& Schäfer-Verwimp, 1987)、越南 (Zhu \& Lai, 2003)、斐济(Pócs \& Eggers, 2007; Pócs, 2015)和泰国(He et al., 2012; Inuthai et al., 2014; Promma \& Chantanaorrapint, 2015)等国家也先后有 叶附生苔的研究报道。1964年陈邦杰和吴鹏程发表 的《中国叶附生苔类植物的研究(一)》是我国有关 叶附生苔研究的最重要的早期文献报道, 文中详细 记述了中国叶附生苔的研究历史、叶附生苔特征、 环境适应特点, 以及它们的地理分布, 共详细描述 了76种叶附生苔。随后, 中国许多学者陆续报道了 西藏(吴鹏程和罗健馨，1978)、江西(李登科和吴鹏 程, 1988; 季梦成和吴鹏程, 1996; 季梦成和刘仲苓, 1998a, 1998b; 季梦成等, 1998, 2001, 2005; Ji et al., 1999)、福建(吴鹏程等, 1984; 李登科, 1997; 朱俊等, 2001)、广东(李植华和吴鹏程, 1992)、湖南(李登科, 1990)、海南(吴鹏程和林邦娟, 1994; 师雪芹, 2008; Wang et al., 2014)、广西(胡舜士等, 1981; Wang \& Jia, 1993; 南紫和朱瑞良, 2007)、贵州(吴鹏程和林 齐维, 1988)、浙江(朱瑞良和胡人亮, 1991; 朱瑞良 等, 1992; Zhu et al., 1994)、安徽(吴鹏程和郭新弧, 1986)、湖北(彭丹等, 2002)等地的叶附生苔。

在美洲地区, 美国佛罗里达州的南部(Redfearn Jr., 1952)、南卡罗来纳州和北卡罗来纳州、肯塔基 
州以及田纳西州境内的阿巴拉契亚山(Appalachian) (Schuster, 1959; Risk et al., 2011)、乔治亚州的 Thomas县(Ellis, 1971)、路易斯安那州(Guerke, 1973) 以及阿拉巴马州南部(Diamond et al., 1999)均有关 于叶附生苔的研究报道。墨西哥的Chiapas发现了 26 种叶附生苔(Equihua \& Pócs, 1999), 哥伦比亚的 Chocó仅在 $800 \mathrm{~km}^{2}$ 的区域内就发现了 72种叶附生苔 (Benavides \& Sastre-De Jesús, 2011)。

此外, 非洲赞比亚(Pócs，1974)、尼日利亚 (Olarinmoye, 1974)、几内亚(Müller \& Pócs, 2007)和 毛里求斯(Ah-Peng \& Bardat, 2009)等国, 欧洲的英 国奇尔特恩山(Porley, 1996), 大洋洲的澳大利亚昆 士兰(Pócs \& Streimann, 1999)和新喀里多尼亚(Zhu \& Müller, 2012)等地也有叶附生苔的发现和报道。

由于还有很多地区未调查到, 且有些种类尚待 分类学修订, 迄今为止, 叶附生苔到底有多少种, 尚无准确的数据。1990年, Luo (1990)发表专文《A synopsis of Chinese epiphyllous liverworts》列出了中 国的102种叶附生苔, 隶属于11科32属, 其中, 细鳞 苔科(Lejeuneaceae) 是种类最多的科, 有21属85种, 疮鳞苔属(Cololejeunea) 是种类最多的属, 有21种。 1996年, 匈牙利苔藓学家Pócs (1996)综述了全球叶 附生苔的物种多样性, 共收录了 1000 种典型的叶 附生苔, 其中, 病鳞苔属389种、角茓苔属(Ceratolejeunea) 114种、角鳞苔属(Drepanolejeunea) 98种、 管叶苔属(Colura) 76种、双鳞苔属(Diplasiolejeunea) 68种、齿鳞苔属(Prionolejeunea) 59种、小鳞苔属 (Aphanolejeunea) 54种、薄鳞苔属(Leptolejeunea) 48 种、纤鳞苔属 (Microlejeunea) 34 种、扁䓵苔属 (Radula) 13种, 以及其他物种数少于 10 的 12 个属。 这些叶附生苔在亚洲、大洋洲、非洲、美洲和欧洲 均有分布, 其中, 亚洲叶附生苔物种数量最多, 达 500多种, 美洲次之, 有 375种。1999年, Diamond等 (1999)报道美国阿拉巴马州的叶附生苔时, 列出了 在美国南部地区发现的叶附生苔种类有唇鳞苔属 (Cheilolejeunea) 1种、病鳞苔属3种、双鳞苔属2种、 角鳞苔属 2 种、细鳞苔属 (Lejeunea) 3种、白鳞苔属 (Leucolejeunea) 2种、直鳞苔属(Rectolejeunea) 1 种、 耳叶苔属(Frullania) 3种、叉苔属(Metzgeria) 1种。 此后, Risk等(2011)又在美国东北部发现了10种叶附 生苔, 其中细鳞苔属、白鳞苔属和扁荌苔属各有一 种是新记录。2001年, Zhu和So发表的《Epiphyllous
Liverworts of China》中收录了中国叶附生苔植物 168 种, 隶属于护蒴苔科(Calypogeiaceae)、大萼苔科 (Cephaloziaceae)、耳叶苔科(Frullaniaceae)、地蕶苔 科(Geocalycaceae)、毛耳苔科(Jubulaceae)、叶苔科 (Jungermanniaceae)、细鳞苔科、叉苔科(Metzgeriaceae)、羽苔科(Plagiochilaceae)、扁荌苔科(Radulaceae)等10科, 共28属, 其中细鳞苔科是种类最多 的科, 有 19 属 138 种, 疮鳞苔属是种类最多的属, 有 63 种。近些年来, 关于叶附生苔植物的新种、新记 录仍然时有报道。Pócs等陆续发表了一系列这方面 的文章《New or little known epiphyllous liverworts (IX-XIX)》(Pócs, 2002, 2006, 2011; Eggers \& Pócs, 2006; Pócs \& Sass-Gyarmati, 2006; Pócs \& Ninh, 2012; Pócs \& Bemecker, 2013; Pócs et al., 2013)。

尽管关于叶附生苔的研究历史悠久, 但对于苔 藓植物学者而言, 叶附生苔仍属于一个比较陌生的 类群, 这归各于在野外发现它们的困难性、对其类 型划分的不确定性等。以中国为例, 2001年统计的叶 附生苔种类为168种(Zhu \& So, 2001), 经过10多年 的探索发现, 最新的《中国生物物种名录》(贾渝和 何思, 2013)中有些名称已经发生了变化, 叶附生苔 的种类数量也发生了变化。对于世界范围的叶附生 苔而言, 其资料更为复杂, 有待于进一步开展其多 样性分析。

\section{2 叶附生苔的分布格局}

\section{1 叶附生苔的地理分布}

一般认为, 叶附生苔的分布局限于降水非常丰 富的热带和亚热带地区, 赤道南北纬度 $30^{\circ}$ 之间(陈 邦杰和吴鹏程, 1964; Pócs, 1996; Zhu \& So, 2001)。 但是, 叶附生苔在北纬 $30^{\circ}$ 以北的地区也不断地被 发现, 如中国湖北后河自然保护区 $\left(30.08^{\circ} \mathrm{N}\right)$ (彭丹 等, 2002)和四川都江堰 $\left(31^{\circ} \mathrm{N}\right)(\mathrm{Luo}, 1990)$ 、葡萄牙 的马德拉群岛 $\left(32.5^{\circ} \mathrm{N}\right)$ (Sjögren, 1975)和亚速尔群 岛 (38.5 N)(Sjögren，1997)、日本四国岛 $\left(33.75^{\circ}\right.$ $\mathrm{N})\left(\right.$ Kamimura, 1939) 和新瀉县 $\left(38^{\circ} \mathrm{N}\right)($ Shirasaki, 1997)、美国阿巴拉契亚山(35.0-37.97º N)(Schuster, 1959; Davison, 1997; Risk et al., 2011)、俄罗斯高加 索山(43.5 N)(Pócs, 1982)、加拿大不列颠哥伦比亚 省 $\left(49.42^{\circ} \mathrm{N}\right)($ Vitt et al., 1973)以及英国的奇尔特恩 山 $\left(51.75^{\circ} \mathrm{N}\right)($ Porley, 1996)等均有分布。

陈邦杰和吴鹏程(1964)认为叶附生苔的世界分 
布区主要在印度-马来地区、南美洲亚马逊河流域、 中美洲、非洲刚果河流域, 其向南达澳大利亚的昆 士兰, 北及韩国的济州岛, 日本的四国岛、小笠原诸 岛和琉球群岛。Pócs (1996)分析叶附生苔植物有21 个地理分布区系(图1): AND, 安第斯山脉; ANT, 安 的列斯群岛; AUA, 澳大利亚、塔斯马尼亚、新西兰 和附近南太平洋诸岛; CAF, 刚果民主共和国、卢旺 达和布隆迪; EAF, 东非埃塞俄比亚至莫桑比克; GUI, 圭亚那; ICH, 中南半岛的孟加拉吉大港丘陵 地区至越南; IND, 印度及喜马拉雅山、卡西丘陵、 孟加拉和斯里兰卡; LSA, 南美亚马逊河流域和其 他低地如乔科省和奥里诺科河流域; MAC, 马卡罗 尼西亚; MAD, 马达加斯加、塞舌尔、科摩罗和马 斯克林群岛; MAL, 东南亚群岛; MEL, 包括新几内
亚、新不列颠、俾斯麦、所罗门群岛、新赫布里底 群岛和新喀里多尼亚等的美拉尼西亚; MEA, 墨西 哥到巴拿马; OAS, 中国、韩国和日本南部的琉球群 岛等东亚地区; OCE, 火山列岛和加罗林群岛至夏威 夷群岛、斐济至复活节岛的大洋洲太平洋地区; SAF, 南非; SBR, 巴西东南部高原以及巴拉圭和阿根廷的 米西奥内斯省; TSA, 南美温带地区; USA, 美国东南 部; WAF, 西非几内亚至刚果。然而, 这些地理分布 区系中并未包含所有叶附生苔分布地区，如加拿大 不列颠哥伦比拉省和英国奇尔特恩山(图1)。

叶附生苔在美国的分布区前面已描述, 主要是 在美国的东南部, 佛罗里达州中部以北地区 $\left(27.5^{\circ}\right.$ $37.97^{\circ} \mathrm{N}$, 图2) (Risk et al., 2011)。在中国, 叶附生苔 的分布大多在北纬 $30^{\circ}$ 以南(陈邦杰和吴鹏程, 1964)。

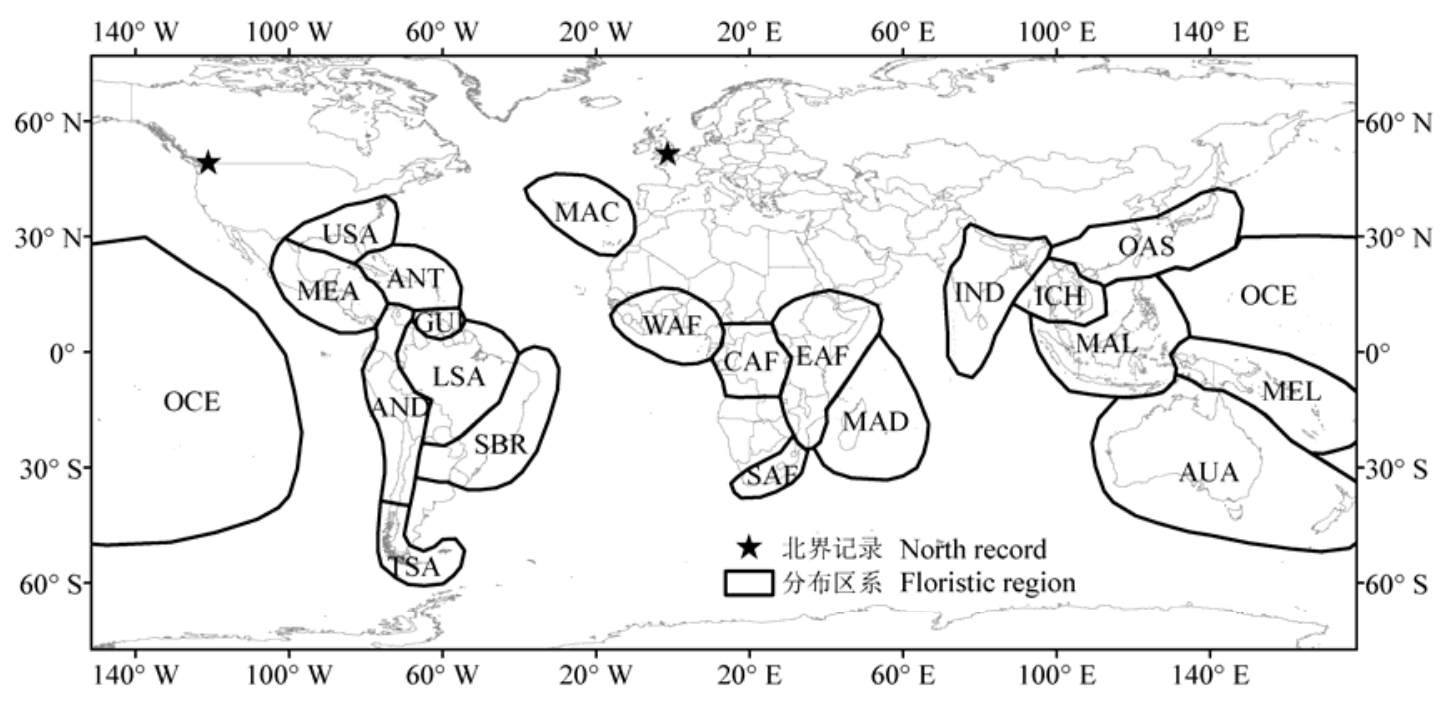

图1 叶附生苔植物的地理分布区系及北界记录。 丸代表的北界记录分别是加拿大不列颠哥伦比亚省和英国奇尔特恩山。 AND, 安第斯山脉; ANT, 安的列斯群岛; AUA, 澳大利亚、塔斯马尼亚、新西兰和附近南太平洋诸岛; CAF, 刚果民主共和国、 卢旺达和布隆迪; EAF, 东非埃塞俄比亚至莫桑比克; GUI, 圭亚那; ICH, 中南半岛的孟加拉吉大港丘陵地区至越南; IND, 印 度及喜马拉雅山、卡西丘陵、孟加拉和斯里兰卡; LSA, 南美亚马逊河流域和其他低地如乔科省和奥里诺科河流域; MAC, 马 卡罗尼西亚; MAD, 马达加斯加、塞舌尔、科摩罗和马斯克林群岛; MAL, 东南亚群岛; MEL, 包括新几内亚、新不列颠、俾 斯麦、所罗门群岛、新赫布里底群岛和新喀里多尼亚等的美拉尼西亚; MEA, 墨西哥到巴拿马; OAS, 中国、韩国和日本南部 的琉球群岛等东亚地区; OCE, 火山列岛和加罗林群岛至夏威夷群岛、斐济至复活节岛的大洋洲太平洋地区; SAF, 南非; SBR, 巴西东南部高原以及巴拉圭和阿根廷的米西奥内斯省; TSA, 南美温带地区; USA, 美国东南部; WAF, 西非几内亚至刚果。21 个地理分布区系的划分参照Pócs (1996)。

Fig. 1 Floristic regions where epiphyllous liverworts occur. $\star$ represents the north records of British Columbia and Chiltern Hills, England. AND, The Andes; ANT, The Antilles; AUA, Australasia, including Australia, Tasmania, New Zealand and the neighbouring islands; CAF, Central Africa including Zaire, Rwanda and Burundi, EAF, East Africa from Ethiopia to Mozambique; GUI, The Guyanas; ICH, Indochina from the Chittagong Hills of Bangladesh to Vietnam; IND, India with the Himalayas, Khasia Hills and lowland Bangladesh and Sri Lanka; LSA, Amazonia and other lowland parts of South America such as Choco and the Orinoco basin; MAC, Macaronesia; MAD, Madagascar and the Seychelles, Comoro and Mascarene Islands; MAL, The Malesian Archipelago; MEA, Mesoamerica from Mexico to Panama; MEL, Melanesia, including the whole New Guinea, New Britain, the Bismarck and Solomon Islands, New Hebrides and New Caledonia ; OAS, East Asia including China, South Korea and Southern Japan; OCE, Oceania, the Pacific from Volcano and the Carolines to Hawaiian Islands and from Fiji to Easter Islands. SAF, South Africa; SBR, The southeastern highlands of Brazil, with Paraguay and the Province Misiones in Argentina; TSA, temperate South America; USA, the southeastern part of United States; WAF, West Africa from Guinea to the Congo. 21 floristic regions were drawn according to Pócs (1996). 


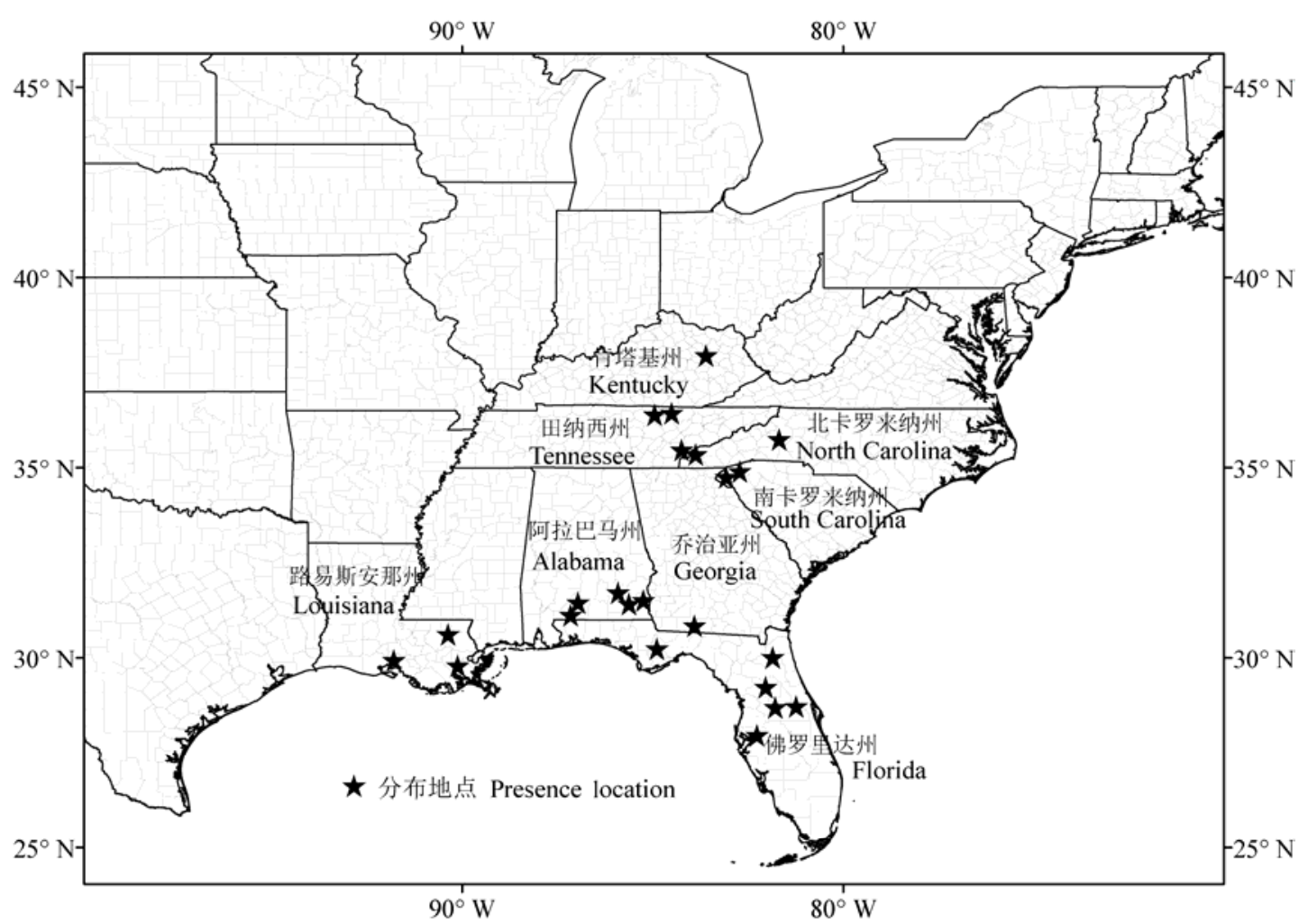

图2 叶附生苔植物在美国的分布地点。物种分布记录从Risk等(2011)中获取。

Fig. 2 Occurrences of epiphyllous liverworts in USA. Presence localities were obtained from Risk et al. (2011).

但随着调查的深入, 发现它们的范围也在逐渐地扩 大，在纬度带上向北推移至北纬 $31^{\circ}$, 如四川省的都 江堰(Luo, 1990)和湖北省的后河自然保护区(彭丹 等, 2002); 在经度带上, 中国最西的记录是西藏墨 脱地区 $\left(95^{\circ} \mathrm{E}\right)($ 吴鹏程和罗健馨，1978)。迄今为止, 在中国有叶附生苔记录的省、自治区或特别行政区 有海南、广东、香港、广西、云南、西藏、福建、 台湾、贵州、湖南、江西、浙江、安徽、四川和湖 北等; 5 个分布中心是: 海南、台湾、浙江西南部和 福建北部、云南南部和西北部, 以及西藏东南部 (Zhu \& So, 2001)。近几年, 本文作者根据叶附生苔 的分布点及影响其分布的环境因子, 通过模型模拟 出了叶附生苔在中国的潜在分布区: 南起海南, 北 达重庆, 东至浙江, 西及西藏; 尤其在西藏南部的 林芝地区、云南西双版纳地区、海南岛、台湾和福 建的大部分地区, 还有广东与广西交界处、广东与 江西交界处等地叶附生苔出现的概率较高, 叶附生 苔存在的北界最有可能在重庆北部的大巴山脉 (Jiang et al., 2014)。

综上所述, 对于叶附生苔的地理分布研究, 除 了美国和中国的研究比较充分以外, 其他国家还只
有零星的报道, 缺少系统的分析。因此, 利用模型的 方法预测它们在全球的分布显得很有必要。

\section{2 叶附生苔的附主特性}

叶附生苔对附主的选择是否存在严格的特异性 目前还存在较多的争论。有学者证明, 叶附生苔可 以生长在叶片以外的有机或无机质表面上。 Monge-Nájera和Blanco (1995)将塑料片剪成不同形 状, 放置于哥斯达黎加的热带低地雨林中, 9个月后 发现叶附生群落在不同形状的塑料片和真实叶片上 的繁殖及迁移速度没有显著差异。Berrie和Eze等通 过实验分析了 Radula flaccida 与其附生的不同植物 叶片的生理关系, 结果表明叶附生苔可从其附生的 叶片中汲取水分, 但不吸收有机质(Berrie \& Eze, 1975; Eze \& Berrie, 1977)。而Wanek和Pörtl (2005) 的研究却表明, 叶附生苔所获取的营养物质除了来 源于雨水和固氮作用外, 还有一部分直接来自于其 附生叶片上的渗滤液(leachates), 它们所吸收的氮 含量会随附主种类的不同而存在较大差异。

叶附生苔的组成与附生叶片的物理性质密切相 关, 如叶片的年龄、大小、硬度、厚度、表皮质地、 光滑度、黏着度以及表面的导水性等(Coley et al., 
1993; Pócs \& Tóthmérész, 1997)。 Monge-Nájera (1989)通过分析胡椒属(Piper)一种灌木叶面上的叶 附生苔, 发现较老的叶片上叶附生苔的盖度较高, 且叶片面积越大, 叶附生苔盖度也越高。总体而言, 叶附生苔趋向于附生在某些类群的植物叶片上, 如 常绿、叶厚、硬革质且较光滑的叶片 (Zhu \& So, 2001), 主要是一些壳斗科、茶科、茜草科、兰科、 菖麻科和硕类植物等(陈邦杰和吴鹏程, 1964)。

\section{3 叶附生苔的生境}

发现叶附生苔的地点均是降水多或湿度高的地 区，或为峡谷型地貌，或有完整的热带雨林或常绿 阔叶林, 这些都为叶附生苔的繁殖、生长以及多样 性的增加与维持提供了必要条件(Schuster, 1959; Pócs, 1996)。林冠层发育好、干扰少有利于叶附生 苔的繁殖和生长(Zartman, 2003; Sonnleitner et al., 2009; Benavides \& Sastre-De Jesús, 2011)。由于对湿 度的特殊要求, 叶附生苔的附着高度通常不超过3 $m$ (陈邦杰和吴鹏程, 1964), 只有在云雾森林或者非 常湿润的热带雨林中叶附生苔才会生长在林冠层上 (Pócs, 1996)。林冠层的密度对叶附生苔的多样性和 丰富度也有明显的影响, 浓密的冠层下能够生长更 多的叶附生苔(Silva \& Pôrto, 2010)。叶附生苔的生 长对海拔也有一定的要求, 由于低海拔人为活动的 影响, 它们更适于在海拔稍高处生长(Silva \& Pôrto, 2010)。如叶附生苔在中国分布的海拔范围为 30-3000 m, 其中最适合的海拔为700-1 $600 \mathrm{~m}$, 此 海拔范围也是热带雨林或常绿阔叶林生长范围。此 外, 坡向也有一定影响, 叶附生苔在北大西洋马德 拉群岛 (Madeira) 的山北坡生长得更好 (Sjögren, 1975)。总之, 郁闭的、湿润的热带雨林和常绿阔叶 林才是叶附生苔的适宜生境。

\section{3 叶附生苔物种多样性分布格局的生态成因}

叶附生苔物种多样性形成的主要环境因素包括 光照、温度和空气相对湿度(吴鹏程等, 1987)。

Sonnleitner等(2009)的研究表明较高的相对湿度是 叶附生苔多样性形成的最主要因素, 其物种多样性 和盖度与空气温度、光照, 以及叶片性质相关性较 小, 但物种组成与这些因素都密切相关, Sonnleitner 等(2009)认为未受干扰的林冠层是叶附生群落生长 发育所必需的条件。在尼日利亚进行的研究表明, 该地区常见叶附生苔种类如Radula flaccid、Cauda- lejeunea hanningtonii、Leptolejeunea astroidea和Cololejeunea pusilla var. obtusifolia的生长与降水量高 度正相关, 雾和露水作为干旱季节的降水来源, 是 维持叶附生苔生长的重要因素(Olarinmoye, 1974)。

发育良好的林冠层为叶附生苔群落的生长发育 提供了有利条件。Silva和Pôrto (2010)的研究表明林 冠层的密度对叶附生苔的多样性和丰富度有明显的 影响, 浓密的冠层下能够生长更多的叶附生苔。笔 者前期的研究也表明叶附生苔的出现与常绿阔叶林 的覆盖度密切相关, 只有常绿阔叶林的覆盖度超过 $14 \%$ 时, 叶附生苔才有可能出现, 并且超过此覆盖 度后, 叶附生苔的出现概率与常绿阔叶林的覆盖度 呈显著正相关关系(Jiang et al., 2013)。

森林的完整性和受干扰程度也对叶附生苔物种 多样性的维持和空间分布有重要影响(Pócs，1996; Alvarenga \& Pôrto, 2007; Sonnleitner et al., 2009; Silva \& Pôrto, 2010)。亚马逊森林中叶附生苔的物种 组成和丰富度随森林斑块大小而变化, 连片森林中 的叶附生苔比破碎化森林中的种类多且密度大; 林 冠层发育好、干扰少有利于叶附生苔的繁殖和生长 (Zartman, 2003; Sonnleitner et al., 2009), 在哥伦比亚 乔科(Chocó-Colombia)的天然森林和受干扰的森林 中叶附生苔的物种丰富度、盖度和组成有所差别, 原 始森林中的叶附生苔种类和盖度比次生林中的多且 斑块大(Benavides \& Sastre-De Jesús, 2011)。叶附生苔 生存区若受到外来物种入侵或植树造林的影响, 其 群落就会大量减少甚至完全消失(Pócs, 1996)。

以上概述了叶附生苔多样性形成所需的外界条 件, 有关于它们形成的内在原因的研究甚少。Yu等 (2013)推测, 叶附生苔的进化可能是对叶面这种特 殊生境以及形体微小这种适应特征的选择结果; 而 无性繁殖是叶附生苔适应叶面生活的关键特征 (Kraichak, 2012)。它们进化的具体原因还有待进一 步研究。

\section{4 展望}

温暖湿润的热带及亚热带森林或峡谷等环境下 维管植物的叶面为叶附生苔的生长和多样性的维持 提供了合适的生境。然而, 由于叶附生苔对环境条 件的特殊要求, 它们的分布并不是很广泛, 多样性 程度也不是很高, 因此, 对其多样性的保护值得关 注。要开展对叶附生苔的保护, 保持森林尤其是天 
然林的完整性显得非常重要。

尽管叶附生苔的种类数量并不是很多, 但在一 片小小的植物叶片表面上却可以同时生长多达十几 种叶附生苔。那么, 为什么这些叶附生苔会出现, 这 些叶附生苔群落间, 以及叶附生苔与其附主间到底 存在怎样的关系, 它们如何进行物质交换以及能量 流动? 这些方面的研究已经取得了一些进展, 但是 它们的作用机制以及进化意义尚不清楚, 今后可以 从生理生态和分子方面开展深入研究。

叶附生苔具有重要的生理生态功能, 如光合调 节、固氮以及水分截留等, 还具有指示环境变化尤 其是气候变化和森林完整性的作用。因此, 在全球 变化的大背景下, 研究森林响应的同时, 叶附生苔 在森林生态系统养分和水分循环中的作用, 以及它 们响应环境变化的特征等都值得我们关注。气候和 植被的变化是长期的过程, 我们也有必要对叶附生 苔的生长和群落动态进行长期的监测。Zartman和 Nascimento (2006)提出, 在全球气候变化背景下, 随着时间推移, 确定叶附生苔的分布北界以及监测 它们的分布边界的变化会很有意义。此外, 以往有 关叶附生苔的生态学研究多局限于对热带雨林中叶 附生苔与附主关系, 或具体生境特征的研究, 在较 大尺度如区域尺度或景观尺度上的研究还很少。在 不同地区, 叶附生苔的多样性和种类组成存在很大 差异, 这也预示着它们与气候环境的密切关系, 那 么它们是如何指示这些环境的变化呢? 这也是以往 研究未曾涉及过的。因此, 从大尺度上物种的区系 特征、形态特征、多样性变化等方面深入分析它们 与环境的关系, 探索其中的规律也将是未来研究的 重要方向。

通过这些研究, 可为开展对叶附生苔的多样性 保护, 为森林管理提供前瞻性决策支持; 并对利用 叶附生苔的敏感性来指示森林和气候环境的变化等 具有重要意义。

基金项目 国家自然科学基金(31300356)和中央高 校基本科研业务费专项基金(2662014BQ025)。

致谢 感谢中国科学院植物研究所吴鹏程研究员和 深圳仙湖植物园张力教授在标本数据收集过程中给 予的帮助。

\section{参考文献}

Ah-Peng C, Bardat J (2009). The genus Leptolejeunea (Spruce) Schiffn. (Lejeuneaceae) newly recorded on La Reunion
Island. Cryptogamie Bryologie, 30, 277-280.

Alvarenga LDP, Pôrto KC (2007). Patch size and isolation effects on epiphytic and epiphyllous bryophytes in the fragmented Brazilian Atlantic forest. Biological Conservation, 134, 415-427.

Asthana G, Shukla A (2009). Two epiphyllous species of Drepanolejeunea (Spruce) Schiffn. new to the Indian bryoflora. Journal of Bryology, 31, 139-142.

Asthana G, Shukla A (2010). A new epiphyllous species of Cololejeunea (Lejeuneaceae) from India. Cryptogamie Bryologie, 31, 217-221.

Benavides JC, Sastre-De Jesús I (2011). Diversity and rarity of epiphyllous bryophytes in a superhumid tropical lowland forest of Choco-Colombia. Cryptogamie Bryologie, 32, 119-133.

Berrie GK, Eze JMO (1975). The relationship between an epiphyllous liverwort and host leaves. Annals of Botany, 39, 955-963.

Chen PC, Wu PC (1964). Study on epiphyllous liverworts of China (I). Acta Phytotaxonomica Sinica, 9, 213-276. (in Chinese with English abstract) [陈邦杰, 吴鹏程 (1964). 中国 叶附生苔类植物的研究(一). 植物分类学报, 9, 213-276.]

Coley PD, Kursar TA, Machado J-L (1993). Colonization of tropical rain forest leaves by epiphylls: Effects of site and host plant leaf lifetime. Ecology, 74, 619-623.

Davison PG (1997). Epiphyllous liverworts newly discovered in the Southern Appalachians. Castanea, 62, 215-218.

Dey M, Singh D, Singh DK (2008). A new species of Cololejeunea (Hepaticae: Lejeuneaceae) from Eastern Himalaya, India. Taiwania, 53, 258-263.

Dey M, Singh DK (2010). Two new epiphyllous Leptolejeunea (Hepaticae: Lejeuneaceae) from Eastern Himalaya, India. Taiwania, 55, 355-362.

Diamond AR, Woods M, Rundell H (1999). Epiphyllous hepatics from Southern Alabama. The Bryologist, 102, 309-313.

Eggers J, Pócs T (2006). New or little known epiphyllous liverworts, XIII. Cololejeunea arfakiana sp. nov. from West Irian (New Guinea). Polish Botanical Journal, 51, 155-158.

Eggers J, Schäfer-Verwimp A (1987). Some liverworts new to Sri Lanka (Ceylon). Journal of Bryology, 14, 531-534.

Ellis EA (1971). Epiphyllous Hepaticae in Southwest Georgia. The Bryologist, 74, 49-51.

Equihua C, Pócs T (1999). Epiphyllous bryophytes from the Lacandon forest, Chiapas, Mexico. The Bryologist, 102, 747-752.

Eze JMO, Berrie GK (1977). Further investigations into the physiological relationship between an epiphyllous liverwort and its host leaves. Annals of Botany, 41, 351-358.

Guerke WR (1973). Epiphyllous Hepaticae in Louisiana. The Bryologist, 76, 201-202.

He Q, Zhu RL, Chantanaorrapint S, Kornochalert S, Printarakul N (2012). Drepanolejeunea laciniata (Lejeuneaceae), a new species from Northern Thailand. Cryptogamie Bry- 
ologie, 33, 291-298.

Hu SS, Jin JM, Jin DJ (1981). Preliminary investigation on bryophytes distribution in evergreen broadleaved forest in Huaping, Guangxi Province. Guihaia, 1, 1-8. (in Chinese) [胡舜士, 金鉴明, 金代均 (1981). 广西花坪林区常绿 阔叶林内苔藓植物分布的初步观察. 广西植物, 1, 1-8.]

Inuthai J, Zhu RL, Chantanaorrapint S (2014). Drepanolejeunea actinogyna (Lejeuneaceae), a new species from Southern Thailand. The Bryologist, 117, 165-169.

Ji MC, Liu ZL (1998a). A preliminary report on epiphyllous liverworts in Wuyishan Nature Reserve of Jiangxi Province. Acta Agriculturae Universititatis Jiangxiensis, 20, 125-127. (in Chinese with English abstract) [季梦成, 刘 仲苓 (1998a). 江西武夷山自然保护区叶附生苔初报. 江西农业大学学报, 20, 125-127.]

Ji MC, Liu ZL (1998b). A preliminary report on the epiphyllous liverworts from Jiuling Mufu mountains of Jiangxi Province, China. Journal of Natural Museum, (16), 13-16. (in Chinese with English abstract) [季梦成, 刘仲苓 (1998b). 九岭、幕阜 山叶附生苔初报. 自然博物馆学报, (16), 13-16.]

Ji MC, Liu ZL, Zhang ZY, Chen YJ, Luo LC (1999). The epiphyllous liverworts of Jiangxi Province, Southeast China. Chenia, 6, 105-107.

Ji MC, Luo SY, Chen YJ (2001). A study on the epiphyllous liverworts from Matoushan Nature Reserve of Jiangxi Province, China. Acta Agriculturae Universititatis Jiangxiensis, 23, 467-472. (in Chinese with English abstract) [季梦成, 罗嗣义, 陈拥军 (2001). 江西马头山自 然保护区叶附生苔类植物研究. 江西农业大学学报, 23, 467-472.]

Ji MC, Wu PC (1996). Studies on epiphyllous liverworts of China (VII)-Supplement of epiphyllous liverworts from Jinggangshan, Jiangxi Province. Journal of Nanchang University, 20, 327-329. (in Chinese with English abstract) [季梦成, 吴鹏程 (1996). 中国叶附生苔类植物 的研究(七)一一井冈山的叶附生苔类补遗. 南昌大学学 报, 20, 327-329.]

Ji MC, Xie QH, Liu ZL, Zhang ZY, Chen YJ (1998). Study on the epiphyllous liverworts from Jiulianshan Nature Reserve of Jiangxi Province, China. Journal of Wuhan Botanical Research, 16, 33-38. (in Chinese with English abstract) [季梦成, 谢庆红, 刘仲苓, 张志勇, 陈拥军 (1998). 江西九连山自然保护区叶附生苔研究. 武汉植 物学研究, 16, 33-38.]

Ji MC, Zheng G, Xie Y, Wu HP, Qiang S (2005). Epiphyllous liverworts from Guanshan Nature Reserve of Jiangxi Province. Journal of Zhejiang Forestry College, 22, 370-374. (in Chinese with English abstract) [季梦成, 郑 钢, 谢云, 吴和平, 强胜 (2005). 江西省官山自然保护 区叶附生苔类植物. 浙江林学院学报, 22, 370-374.]

Jia Y, He S (2013). Species Catalogue of China. Science Press,
Beijing. (in Chinese) [贾渝, 何思 (2013). 中国生物物种 名录. 科学出版社, 北京.]

Jiang Y, de Bie CAJM, Wang T, Skidmore AK, Liu X, Song S, Shao X (2013). Hyper-temporal remote sensing helps in relating epiphyllous liverworts and evergreen forests. Journal of Vegetation Science, 24, 214-226.

Jiang Y, Wang T, de Bie CAJM, Skidmore AK, Liu X, Song S, Zhang L, Wang J, Shao X (2014). Satellite-derived vegetation indices contribute significantly to the prediction of epiphyllous liverworts. Ecological Indicators, 38, 72-80.

Kamimura M (1939). Studies on the epiphyllous Hepaticae and its attached plants in Sikoku, Japan. Japanese Journal of Botany, 15, 63-83.

Kraichak E (2012). Asexual propagules as an adaptive trait for epiphylly in tropical leafy liverworts (Lejeuneaceae). American Journal of Botany, 99, 1436-1444.

Li DK (1990). Preliminary report on the epiphyllous liverworts in Hunan Province, China. Inverstigatio et Atudium Naturae, 10, 137-140. (in Chinese with English abstract) [李登科 (1990). 湖南叶附生苔初报. 考察与研究, 10, 137-140.]

Li DK (1997). A study on epiphyllous liverworts of Wanmulin Natural Reserve in Fujian Province, China. Chenia, 3-4, 63-68. (in Chinese with English abstract) [李登科 (1997). 福 建万木林保护区叶附生苔类的研究. Chenia, 3-4, 63-68.]

Li DK, Wu PC (1988). A study on epiphyllous liverworts of China (IV)—The epiphyllous liverworts on Jinggangshan, Jiangxi Province. Inverstigatio et Atudium Naturae, 8, 38-42. (in Chinese with English abstract) [李登科, 吴鹏 程 (1988). 中国叶附生苔类植物研究(四)——江西井冈 山叶附生苔类. 考察与研究, 8, 38-42.]

Li ZH, Wu PC (1992). Studies of epiphyllous liverworts in China (V)_E Epiphyllous liverworts in Heishiding Natural Reserve, Guangdong Province. Botanical Journal of South China, (1), 23-27. (in Chinese with English abstract) [李植华, 吴鹏程 (1992). 中国叶附生苔类植物 的研究(五)一一东黑石顶自然保护区的叶附生苔类. 华南植物学报, (1), 23-27.]

Luo J-S (1990). A synopsis of Chinese epiphyllous liverworts. Tropical Bryology, 2, 161-166.

Massart J (1898). Les végétaux épiphylles. Annales du Jardin botanique de Buitenzorg, Suppl. 2, 161-166.

Mizutani M (1966). Epiphyllous species of Lejeuneaceae from Sabah (North Borneo). The Journal of the Hattori Botanical Laboratory, 29, 153-170.

Monge-Nájera J (1989). The relationship of epiphyllous liverworts with leaf characteristics and light in Monte-Verde, Costa-Rica. Cryptogamie Bryologie Lichenologie, 10, 345352.

Monge-Nájera J, Blanco MA (1995). The influence of leaf characteristics on epiphyllic cover: A test of hypotheses with artificial leaves. Tropical Bryology, 11, 5-9.

www.plant-ecology.com 
Müller F, Pócs T (2007). A contribution to the knowledge of epiphyllous bryophytes of Bioko Island (Equatorial Guinea), including additional remarks on non-epiphyllous species. Journal of Bryology, 29, 81-94.

Nan Z, Zhu RL (2007). Epiphyllous liverworts of the Maoershan Nature Reserve, Guangxi, China. Journal of East China Normal University (Natural Science), (6), 125-130. (in Chinese with English abstract) [南紫, 朱瑞良 (2007). 广西猫儿山自然保护区的叶附生苔类植物. 华东师范 大学学报(自然科学版), (6), 125-130.]

Olarinmoye SO (1974). Ecology of epiphyllous liverworts: Growth in 3 natural habitats in Western Nigeria. Journal of Bryology, 8, 275-289.

Pande SK, Misra RN (1943). Studies in Indian Hepaticae. II. On epiphyllous liverworts of India and Ceylon. Journal of the Indian Botanical Society, 22, 159-169.

Peng D, Liu SX, Wu PC (2002). Studies on the epiphyllous liverworts of China (VIII)-The epiphyllous liverworts of Houhe National Nature Reserve. Journal of Wuhan Botanical Research, 20, 199-201. (in Chinese with English abstract) [彭丹, 刘胜祥, 吴鹏程 (2002). 中国叶附生苔 类植物的研究(八)——湖北后河自然保护区的叶附生苔 类. 武汉植物学研究, 20, 199-201.]

Pócs T (1974). Epiphyllous Liverworts from Zambia. Bulletin de I'Academie Polonaise des Sciences-Serie des Sciences Biologiques, 22, 851-853.

Pócs T (1982). An epiphyllous liverwort community from the Caucasus Mountains. Bryologische Beiträge, 1, 13-22.

Pócs T (1996). Epiphyllous liverworts diversity at worldwide level and its threat and conservation. Anales del Instituto de Biologia de la Universidad Nacional Autonoma de Mexico Serie Botanica, 67, 109-127.

Pócs T (2002). New or little known epiphyllous liverworts, IX. Two new neotropical Cololejeunea species. Acta Botanica Hungarica, 44, 371-382.

Pócs T (2006). New or little-known epiphyllous liverworts, X. On two neotropical Diplasiolejeunea species. The Bryologist, 109, 408-414.

Pócs T (2011). New or little known epiphyllous liverworts, XIV. The genus Colura (Lejeuneaceae) in Sao Tome Island, with the description of Colura thomeensis sp. nov. The Bryologist, 114, 362-366.

Pócs T (2015). Bryophytes from the Fiji Islands, VII. Cololejeunea renneri sp. nov. (Lejeuneaceae, Marchantiophyta). Plant Science Today, 2, 126-128.

Pócs T, Bemecker A (2013). New or little known epiphyllous liverworts, XIX. Cololejeunea yelitzae, a new neotropical species. Acta Botanica Hungarica, 55, 385-391.

Pócs T, Eggers J (2007). Bryophytes from the Fiji Islands. II. An account of the genus Colura, with a description of $C$. vitiensis sp. nov. Polish Botanical Journal, 52, 81-92.

Pócs T, Luong T-T, Ho B-C (2013). New or little known epi- phyllous liverworts, XVIII. Records from the Bidoup-Núi Bà National Park, Vietnam, with the description of Drepanolejeunea bidoupensis, sp. nov. Cryptogamie Bryologie, 34, 287-298.

Pócs T, Ninh T (2012). New or little known epiphyllous liverworts, XVII. Records from the Cát Tiên National Park, Southern Vietnam. Acta Biologica Plantarum Agriensis, 2, 11-19.

Pócs T, Sass-Gyarmati A (2006). New or little known epiphyllous liverworts, XII. Archilejeunea helenae Pócs \& Gyarmati, sp. nova. Cryptogamie Bryologie, 27, 103-109.

Pócs T, Streimann H (1999). Epiphyllous liverworts from Queensland, Australia. Bryobrothera, 5, 165-172.

Pócs T, Tóthmérész B (1997). Foliicolous bryophyte diversity in tropical rainforest. Abstracta Botanica, 21, 135-144.

Porley RD (1996). Foliicolous Metzgeria fruticulosa on box leaves in the Chiltern Hills, England. Journal of Bryology, 19, 188-189.

Promma C, Chantanaorrapint S (2015). The epiphyllous Radula (Radulaceae, Marchantiophyta) in Thailand, with the description of Radula grandilobula sp. nov. Cryptogamie Bryologie, 36, 217-234.

Redfearn Jr. PL (1952). The Bryophytes of Central and Southern Florida. The Bryologist, 55, 193-210.

Risk AC, Richardson C, Davison P (2011). Epiphyllous bryophytes in the Appalachian Plateau of Kentucky and Tennessee, U.S.A. The Bryologist, 114, 289-297.

Schiffner N (1929). Ueber epiphylle Lebermoose aus Japan nebst einigen beobachtungen ueber Rhizoiden, Elateren und Brutkoerper. Annales Bryologici, 2, 87-106.

Schuster RM (1959). Epiphyllous Hepaticae in the Southern Appalachians. The Bryologist, 62, 52-55.

Shi XQ (2008). Epiphyllous liverworts of the Bawangling Nature Reserve, Hainan, China. Journal of Anhui Normal University (Natural Science), 31, 265-268. (in Chinese with English abstract) [师雪芹 (2008). 海南霸王岭自然 保护区叶附生苔类植物. 安徽师范大学学报(自然科学 版), 31, 265-268.]

Shirasaki H (1997). Distribution and ecology of the epiphyllous liverwort Cololejeunea nakajimae in the winter snow-covered district of Niigata Prefecture and its adjacent regions, Central Japan. Bryological Research, 7, 1-7.

Silva MPP, Pôrto KC (2010). Spatial structure of bryophyte communities along an edge-interior gradient in an Atlantic Forest remnant in Northeast Brazil. Journal of Bryology, 32, 101-112.

Sjögren E (1975). Epiphyllous bryophytes of Madeira. Scensk Botanisk Tidskrift, 69, 217-288.

Sjögren E (1997). Epiphyllous bryophytes in the Azores Islands. Arquipélago Life and Marine Sciences, 15A, 1-49.

Sonnleitner M, Dullinger S, Wanek W, Zechmeister H (2009). Microclimatic patterns correlate with the distribution of epiphyllous bryophytes in a tropical lowland rain forest in 
Costa Rica. Journal of Tropical Ecology, 25, 321-330.

Stephani F (1900). Species Hepaticarum. Vol. I. Georg \& Cie, Genève et Bale, Swiss; Même Maison, Lyon, France.

Stephani F (1906). Species Hepaticarum. Vol. II. Georg \& Cie, Genève et Bale, Swiss; Même Maison, Lyon, France.

Stephani F (1906-1909). Species Hepaticarum. Vol. III. Georg \& Cie, Genève et Bale, Swiss; Même Maison, Lyon, France.

Stephani F (1909-1912). Species Hepaticarum. Vol. IV. Georg, Georg \& Cie, Genève et Bale, Swiss; Même Maison, Lyon, France.

Stephani F (1912-1917). Species Hepaticarum. Vol. V. Georg \& Cie, Genève et Bale, Swiss; Même Maison, Lyon, France.

Stephani F (1924). Species Hepaticarum. Vol. VI. Georg \& Cie, Genève et Bale, Swiss; Même Maison, Lyon, France.

Vitt DH, Ostafichuk M, Brodo IM (1973). Foliicolous bryophytes and lichens of Thuja plicata in western British Columbia. Canadian Journal of Botany, 51, 571-580.

Wanek W, Pörtl K (2005). Phyllosphere nitrogen relations: Reciprocal transfer of nitrogen between epiphyllous liverworts and host plants in the understory of a lowland tropical wet forest in Costa Rica. New Phytologist, 166, 577-588.

Wang J, Zhou L-Y, Zhu R-L (2014). A new epiphyllous species of Cololejeunea (Lejeuneaceae, Marchantiophyta) from China. Phytotaxa, 161(2), 165-168.

Wang MZ, Jia Y (1993). A preliminary study of Hepaticae from Mt. Jiuwan of Guangxi, South China. Chenia, 1, $125-131$.

Wu PC, Guo XH (1986). A report on the epipyllous liverworts in Anhui Province, China. Acta Phytotaxonomica Sinica, 24, 136-138. (in Chinese with English abstract) [吴鹏程, 郭新弧 (1986). 安徽叶附生苔初报. 植物分类学报, 24, 136-138.]

Wu PC, Li DK, Gao CH (1984). Studies on the epiphyllous liverworts of China (III)— The epiphyllous liverworts on Wuyi Mt., Fujian Province. Wuyi Science Journal, 3, 1-6. (in Chinese with English abstract) [吴鹏程, 李登科, 高彩华 (1984). 中国叶附生苔类植物的研究(三)一一福 建武夷山的叶附生苔. 武夷科学, 3, 1-6.]

Wu PC, Li DK, Gao CH (1987). Preliminary measurement of some ecological factors of the epiphyllous liverworts in Mt. Wuyi. Acta Botanica Sinica, 29, 449-452. (in Chinese with English abstract) [吴鹏程, 李登科, 高彩华 (1987). [福建武夷山叶附生苔类植物着生生境因素的初步测定. 植物学报, 29, 449-452.]

Wu PC, Lin BJ (1994). Studies on the epiphyllous liverworts of China (VI)-The epiphyllous liverworts of Hainan Island. Chenia, 2, 115-120. (in Chinese with English abstract) [吴 鹏程, 林邦娟 (1994). 中国叶附生苔类植物的研究 (六)——海南岛的叶附生苔类. Chenia, 2, 115-120.]

Wu PC, Lin QW (1988). The epiphyllous liverworts in Maolan Libo County, SW China. Guihaia, 8, 335-338. (in Chinese with English abstract) [吴鹏程, 林齐维 (1988). 贵州茂 兰的叶附生苔类. 广西植物, 8, 334-338.]

Wu PC, Luo JX (1978). Studies on the epiphyllous liverworts of China (II) - The epiphyllous liverworts from Tibet. Acta Phytotaxonomica Sinica, 16, 102-112. (in Chinese with English abstract) [吴鹏程, 罗健馨 (1978). 中国叶 附生苔类植物的研究(二)——西藏的叶附生苔. 植物分 类学报, 16, 102-112.]

Yu Y, Heinrichs J, Zhu RL, Schneider H (2013). Empirical evidence supporting frequent cryptic speciation in epiphyllous liverworts: A case study of the Cololejeunea lanciloba complex. PLoS ONE, 8, e84124. doi: 10.1371/journal. pone.0084124.

Zartman CE (2003). Habitat fragmentation impacts on epiphyllous bryophyte communities in Central Amazonia. Ecology, 84, 948-954.

Zartman CE, Nascimento HEM (2006). Are habitat-tracking metacommunities dispersal limited? Inferences from abundance-occupancy patterns of epiphylls in Amazonian forest fragments. Biological Conservation, 127, 46-54.

Zhu J, Wang YF, Zhu RL, Sun SY (2001). Epiphyllous liverworts of the Eastern Jiufeng Mountain, Fujian Province. Journal of East China Normal University (Nature Science), (4), 96-102. (in Chinese with English abstract) [朱 俊, 王幼芳, 朱瑞良, 孙世勇 (2001). 福建鹑峰山东麓 的叶附生苔类植物. 华东师范大学学报(自然科学版), (4), 96-102.]

Zhu RL, Hu RL (1991). A study on the epiphyllous liverworts from Wuyanling of Zhejiang Province. Journal of East China Normal University (Natural Science), (4), 98-105. (in Chinese with English abstract) [朱瑞良, 胡人亮 (1991). 浙江乌岩岭叶附生苔类植物的研究. 华东师范 大学学报(自然科学版), (4), 98-105.]

Zhu RL, Lai MJ (2003). Epiphyllous liverworts from several recent collections from Taiwan, Thailand, and Vietnam. Cryptogamie Bryologie, 24, 265-270.

Zhu RL, Müller F (2012). Cheilolejeunea hyalomarginata, a remarkable new species of Lejeuneaceae (Marchantiophyta) from New Caledonia. The Bryologist, 115, 217-221.

Zhu RL, So ML (2001). Epiphyllous liverworts of China. Nova Hedwigia, 121, 1-418.

Zhu RL, Ye LX, Cai HZ (1994). Epiphyllous liverworts of Fengyangshan Nature Reserve, Zhejiang Province, China. The Bryologist, 97, 277-279.

Zhu RL, Zhang GZ, Mao XR (1992). Resources of epiphyllous liverworts in Baishanzu Nature Reserve of Zhejiang Province. Journal of Plant Resources and Environment, 1, 19-23. [朱瑞良, 章刚正, 毛小荣 (1992). 浙江百山祖 自然保护区叶附生苔资源. 植物资源与环境, 1, 19-23.]

特邀编委: 贾 渝 责任编辑: 王 蒇 


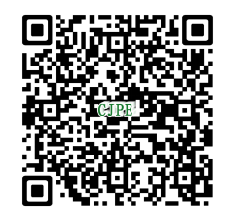

植物生态学报官网

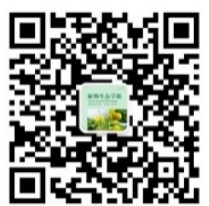

微信订阅号

期刊及学科

相关信息发布

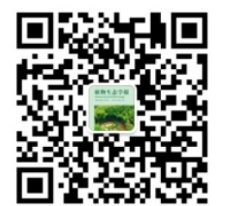

微信服务号

稿件状态查询

全文检索汶览 